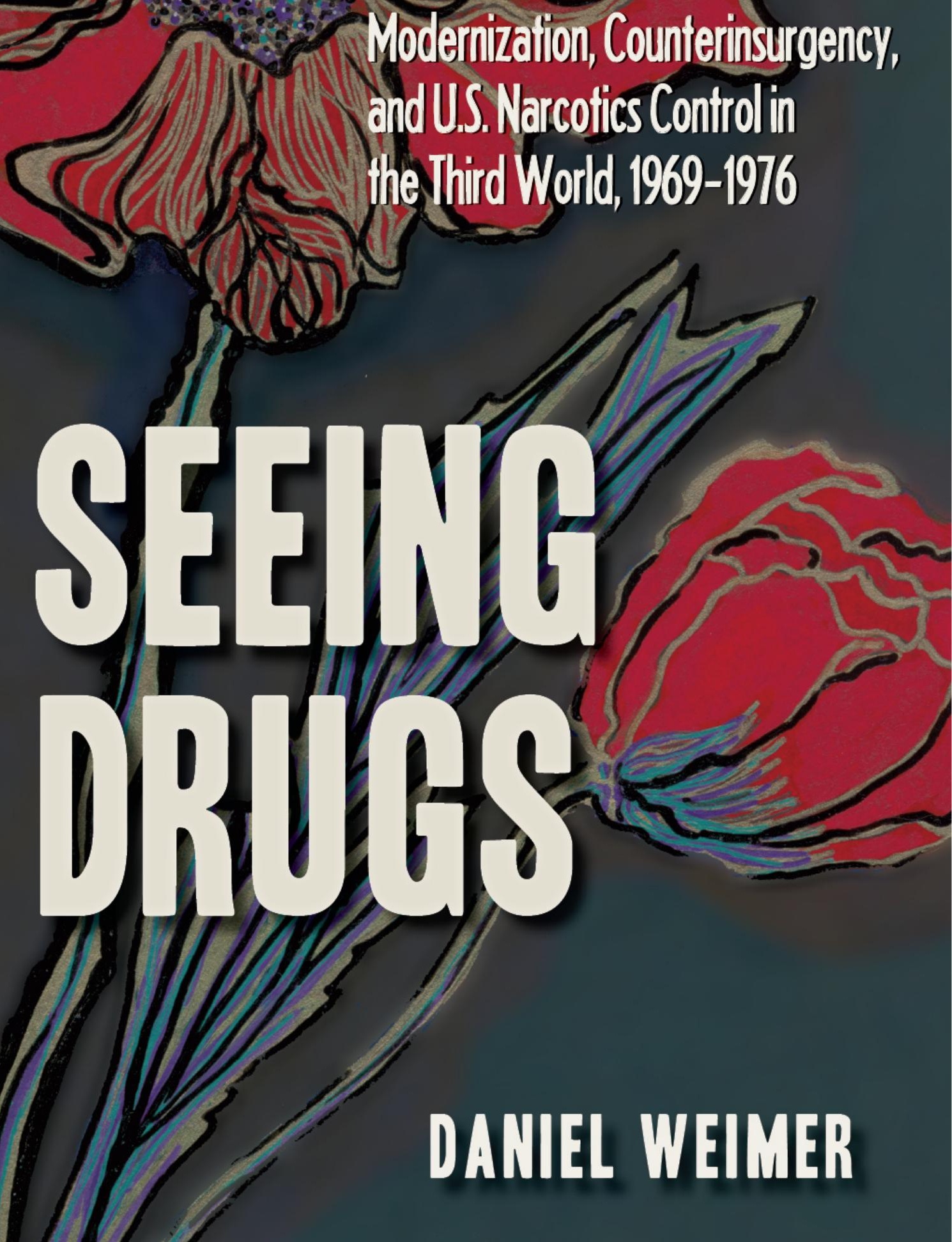




\section{NEW STUDIES IN U.S. FOREIGN RELATIONS}

Mary Ann Heiss, editor

The Birth of Development: How the World Bank, Food and Agriculture Organization, and World Health Organization Changed the World, 1945-1965 AMY L. S. STAPLES

Colombia and the United States: The Making of an Inter-American Alliance, 1939-1960

BRADLEY LYNN COLEMAN

NATO and the Warsaw Pact: Intrabloc Conflicts EDITED BY MARY ANN HEISS AND S. VICTOR PAPACOSMA

Caution and Cooperation: The American Civil War in British-American Relations PHILIP E. MYERS

The Will to Believe: Woodrow Wilson, World War I, and America's Strategy for Peace and Security ROSS A. KENNEDY

Leading Them to the Promised Land: Woodrow Wilson, Covenant Theology, and the Mexican Revolution, 1913-1915

MARK BENBOW

Modernity and National Identity in the United States and East Asia, 1895-1919 CAROL C. CHIN

Seeing Drugs: Modernization, Counterinsurgency, and U.S. Narcotics Control in the Third World, 1969-1976

DANIEL WEIMER 


\title{
Seeing Drugs
}

\author{
Modernization, Counterinsurgency, \\ and U.S. Narcotics Control in the Third World, \\ 1969-1976 \\ Daniel Weimer
}

The Kent State University Press

Kent, Ohio 
(C) 2011 by The Kent State University Press, Kent, Ohio 44242

ALL RIGHTS RESERVED

Library of Congress Catalog Card Number 2011000683

ISBN 978-1-60635-059-1

Manufactured in the United States of America

Permission to reprint material from the author's article "Drugs-as-a-Disease," previously published in the Winter 2003 issue of Janus Head, is gratefully acknowledged.

LIBRARY OF CONGRESS CATALOGING-IN-PUBLICATION DATA

Weimer, Daniel, 1971-

Seeing drugs : modernization, counterinsurgency, and U.S. narcotics control in the Third World, 1969-1976 / Daniel Weimer.

p. cm. - (New studies in U.S. foreign relations) Includes bibliographical references and index. ISBN 978-1-60635-059-1 (hardcover : alk. paper) $\infty$

1. Drug control-United States. 2. Drug control-Developing countries. 3. United States-Foreign relations-2oth century. I. Title.

$$
\begin{gathered}
\mathrm{HV}_{5825 . W_{3} 8332011} \\
363.45097309^{\prime} 047-\mathrm{dc22} \\
2011000683
\end{gathered}
$$

British Library Cataloging-in-Publication data are available. 


\section{Contents}

Acknowledgments vii

$\begin{array}{lll}\text { Abbreviations } & \text { ix }\end{array}$

Introduction: Seeing Drugs 1

1 Drugs and the American Experience 16

2 A Terrible Disease: Metaphors, Identity, and Source Control 50

3 Viewing the Drug Subcultures of the Golden Triangle:

Source Control, COIN, Modernization, and the Hmong in Thailand 85

4 Development as Drug Control: The Intersection of Modernization, Source Control, and Hegemony in Northern Thailand 113

5 The Shan Proposal as the Road Not Taken: The Debate over Alternative Source Control and the Drugs-Security Link in Burma 132

6 "A Quantum Jump in Eradication": Herbicides and Drug Control in Mexico

Conclusion: The Faith in Source Contol and Looking Outward 215

$\begin{array}{ll}\text { Notes } & 229\end{array}$

$\begin{array}{ll}\text { Bibliography } & 286\end{array}$

$\begin{array}{ll}\text { Index } & 309\end{array}$ 


\section{Introduction}

\section{Seeing Drugs}

There is growth everywhere....

Shapes are losing outline, character. Wooden frames turning spongy.

The attrition of squares and rectangles.

The loss of geometry.

-Stephen Wright

On a breezy spring day in early April 1976, President Gerald R. Ford convened a late-morning briefing with numerous administration members to discuss the state of America's global antidrug mission, a policy he had inherited from the founder of the United States' modern drug war, Richard M. Nixon. Among the twenty or so officials assembled in the White House sat the vice president, the director of the Drug Enforcement Administration (DEA), the attorney general, the head of the National Security Agency (NSA), the State Department's coordinator for international narcotics matters, and the director of the National Institute on Drug Abuse. In the darkened meeting room, the policy makers conducted a question and answer session and viewed a slide show highlighting the historical background to drug abuse in the United States, the upsurge in drug use and addiction in the 1960s and 1970s, and current federal drug-control policies at home and abroad. Among the questions that President Ford had asked by the end of the hour and twenty-five-minute meeting were "Who gets the profit from drug trafficking?" and "If we cut off the supply of drugs, what happens to the user?"1

While the Ford administration's drug-control policy encompassed several demand reduction policies, including federal drug treatment and methadone clinics intended to shrink the domestic market for illegal drugs, particularly heroin, the core of the U.S. government's approach to stifling addiction was source control. Since most of the production of illicit drugs, especially drug crops like opium, occurred in Third World nations, U.S. programs for suppressing or eliminating 
drugs at the source ensured Washington's continual intervention in the Third World. But in the literature on the history of American foreign relations, this fact has often gone unexplored. That is, much like the Cold War, which was articulated by American policy makers as a generations-long struggle against an evil foe, the "drug war," the subject of this book, was and is a similarly enduring act of American foreign policy executed in the name of domestic and global security. Thus, this book examines the systems of thought that shaped and justified U.S. global narcotics control during a particularly formative period of the drug war, the Nixon and Ford administrations, and explains why the drug war has persisted as an important, if often unrecognized, feature of American foreign relations.

\section{The Secretary Speaks}

Explaining how to control rampant opium production in Afghanistan in a 17 December 2008 interview, Robert M. Gates, the U.S. secretary of defense, framed the issue as a problem of corruption and the need for "good governance" in that country. In provinces where "good governors" operated, he explained, the Afghans and their NATO allies had achieved "progress" in rooting out corruption and poppy cultivation. Conversely, in provinces with corrupt officials, drug trafficking flourished alongside Taliban insurgents who facilitated and profited from narcotics smuggling. Similarly, a New York Times story of 23 December 2008 on the challenges to containing narcotics trafficking in Afghanistan quoted a security analyst who echoed Gates's phrase of "good governance" as a key element in ending the drug trade and the insurgents' threat to Afghan security. ${ }^{2}$

What is notable about Gates's observation and the New York Times story is the use of the language of counterinsurgency theory (COIN) to explain the solution to insurgency and drug trafficking in Afghanistan. That is, "good governance" forms one of what D. Michael Shafer deemed the "three oughts" of counterinsurgency theory: security, good government, and progress (economic development). Devised in the 1950 s by American policy makers and scholars to thwart Communism in Third World nations, counterinsurgency theory was used by the United States in Asia and Latin America during the Cold War. Washington sought to prevent the spread of Communism by providing weaker nations with both security and economic development. According to counterinsurgency theory, security and development were interdependent. American-trained military and police forces protected Third World governments from (presumably Communist) internal and external threats, thus allowing them to concentrate on domestic development. Economic and political development satisfied domestic demands for improved living conditions and bolstered local stability by lessening the chances 
of internal unrest. As Shafer put it in his scrutiny of American counterinsurgency policy from 1945 to 1965 , "Without security, so the argument goes, development is impossible; without good government and economic progress, efforts to maintain it will be bootless." Tellingly, the security analyst quoted in the New York Times article on Afghanistan reiterated Shafer's words when he concluded that "if the military cannot secure the population, then political development, economic growth and good government will not take place."

For U.S. officials, then, the circumstances in Afghanistan highlighted the interconnection between counterinsurgency and counternarcotics policy. Indeed, the U.S. government's interventions in Afghanistan and Iraq revived official and public interest in counterinsurgency to a higher pitch than any time since the Vietnam War. ${ }^{4}$ Yet the influence of counterinsurgency theory on American policy makers' efforts to curb opium production in Afghanistan had precedent in earlier U.S. drug-control ventures across the globe where the issues of drug trafficking and internal security intersected. What is often unrecognized, and what this book will explore, is that from the very inception of the modern war on drugs in the early 1970 S U.S. drug policy was heavily influenced by counterinsurgency theory and a related system of thought: modernization theory.

\section{The General and His Metaphors}

Eight years before Gates's interview and just prior to the inauguration of the war on terror, another high-profile U.S. official articulated a mode of thought likewise critical to the conception and longevity of the United States' war on drugs. On 27 December 2000, in the wake of that year's controversial presidential election, listeners of National Public Radio's All Things Considered heard an interview with the outgoing "drug czar," General Barry McCaffrey, who relayed his thoughts on the ongoing drug war and the future direction of the nation's drug policy. ${ }^{5} \mathrm{Mc}$ Caffrey recounted for the national audience his service in the Clinton administration and detailed what he considered to be the drug war's successes and failures. A veteran of the Vietnam War, the Gulf War, and now the drug war, McCaffrey stated his central concern: that American citizens and all of the individuals and organizations concerned with drug-control policy needed to change the metaphor through which they conceived the drug problem. The United States, he asserted, must replace the metaphor of "the war on drugs" with the perception of drugs as a "cancer" destroying American society. For McCaffrey, the "war" metaphor fostered a concentration on law enforcement and promoted binary thinking, which too often led to an either-or approach-that is, either supply-side law enforcement or demand-side therapy and rehabilitation. The "cancer" metaphor, he 
believed, would encourage an integrated approach to drug control, in which the nation's resources, the medical community, government, law enforcement, families, and schools would all work together to stem drug abuse. ${ }^{6}$

What McCaffrey failed to mention in his call for using a "cancer" metaphor was that it was not at all new: the idea of drug abuse as a dangerous "disease" had been advanced throughout the twentieth century by many politicians, law enforcement officials, and ordinary citizens, and allows for a variety of interpretations. ${ }^{7}$ Following McCaffrey's line of thinking, viewing drugs as disease can promote a medical solution to addiction or designate addiction as a public health problem. The disease metaphor can also lead to the view that drugs are an outside or foreign agent infecting the U.S. populace. This conception advances a view of drugs as "foreign" and "un-American," which deflects antidrug policy formulation away from demand-side treatment and encourages supply-side solutions. ${ }^{8}$ More importantly, and contrary to McCaffrey's way of thinking, the disease metaphor most definitely promotes binary thinking: normal/pathological, inside/outside, pure/polluted, physician/patient. The effects that the disease metaphor has had on U.S. drug policy, particularly foreign antinarcotics policy, will be explored later. In the meantime, it is worth using McCaffrey's words about the importance of the mind-set that Americans, particularly policy makers, bring to the issue of drug abuse as a jumping-off point for an examination of how the United States has perceived drug control. Through which cultural lenses did the nation view the problem of drug abuse? Through which cultural constructions did it identify the problem and prescribe a solution?

\section{Drugs, Modernization, and Counterinsurgency}

Although McCaffrey's personal experience, like Gates's, pertains to the contemporary drug war, their thoughts on the conceptual framework of drug-control policy are relevant to the antidrug efforts of the Richard M. Nixon and Gerald R. Ford administrations in Thailand, Burma, and Mexico-the focal points of U.S. drugcontrol efforts at the time. The cultural assumptions at the heart of foreign drug policy in these three nations from 1969 to 1976 still resonate in American policy today and also share characteristics with earlier drug policy and foreign policy. In particular, the cultural constructions of modernization theory and counterinsurgency theory greatly informed U.S. policy toward these Third World nations.

Modernization theory was an ideology of progress, as Christopher T. Fisher phrased it. The theory "split the world into antipodal binaries-the traditional and the modern-and claimed that modernity (read as economic growth, technical innovation, mass literacy, unfettered mobility, and urbanization) was a 'syndrome' whose effects were total, universal, and inclined toward secular democra- 
cies like the United States." The passage from tradition to modernity, although universal, was fraught with peril (material and mental), as the destabilizing transition period opened the window for Communist insurgency and that competing but fatally flawed ideology of progress-Communism. For the traditional societies in the Cold War battleground states of the Third World, Fisher noted, the United States proffered modernization as a "blueprint for development that was consistent with America's most treasured values, conceived in the progressive tradition, premised upon social universals, and aggressive in rebuffing Soviet advances." Modernization's aggressive character materialized as counterinsurgency theory, or what Michael E. Latham termed "modernization at war." Counterinsurgency theory claimed the same road to non-Communist economic and sociopolitical development as modernization theory but was applied in battleground areas, such as Vietnam, where in fighting wars against national liberation issues of security and development could not be separated. War's instability presented an environment, according to COIN logic, in which modernization could take hold. To be sure, as Fisher pointed out, modernization and counterinsurgency are two sides of the same coin, two expressions of the "same impulse."

Even as the disaster of nation building in Vietnam soured the validity of modernization for critics of the Right and Left, the enduring nature of the modernizing impulse manifested itself in U.S. drug policy in Southeast Asia and Latin America-though in varying forms and mutations from the grand idea of wholesale societal transformation envisioned during the Kennedy and Johnson years. ${ }^{10}$ Modernization and its wartime variant, counterinsurgency, are flexible and dynamic theories, and their application by U.S. officials in formulating drug-control policies illustrated this. Ron Robin demonstrated that American theorists and policy makers offered two variants of COIN. "Constructive counterinsurgency" constituted the initial version of the theory in the late 1950 s and early 1960s. In this manifestation, nonmilitary policies took precedence and focused on economic, political, and social development within an insurgency environment. As Robin characterized it, "Winning the localized armed struggles of the Cold War assumed that victory hinged upon the allegiance and support of the local population." Thus "modernization at war," by winning hearts and minds, not only would defeat insurgencies by drawing civilian support away from rebels, but also would put a society on the path to greater economic and political prosperity. ${ }^{11}$

An alternative version of COIN theory, "coercive counterinsurgency," emerged in the second half of the 1960 s and contended that economic development was not the key to preventing peasants from supporting Communist insurgents. The United States and its allies in combating insurgencies in the Third World did not need to win hearts and minds, according to this theory; all that was required was to change peasants' behavior-their beliefs and values were secondary or unimportant. In this approach, coercion was paramount because peasants "would 
cease and desist their support for insurgents if the price of such support-punitive measures by government forces-was sufficiently harsh and deterrent." In sum, peasants, faced with state violence that threatened their livelihoods or their lives, would make the "rational choice" to avoid aiding rebels. ${ }^{12}$

In looking at U.S. drug control in Thailand, Burma, and Mexico during the 1970s, what becomes apparent is that the coercive approach to counterinsurgency dominated officials' thinking as they formulated policies in each of these nations, where antistate violence intermingled with narcotics production and trafficking. Only in Thailand (explained below) did COIN's initial "constructive" version of counterinsurgency theory find expression. Ultimately, though, what all modernization and counterinsurgency policies have in common, including the ones analyzed in this book, is an overriding focus on the expansion of state power, government control over a state's territory and population, and political stability. ${ }^{13}$

In the three nations examined in this study-Thailand, Burma, and Mexicocounterinsurgency and modernization theory shaped U.S. drug-control policy. In Thailand during the U.S. Nixon and Ford administrations, counterinsurgency theory influenced Washington's conceptualization of how to combat illicit drug trafficking and provided a theoretical basis for aiding the Thais in creating special antinarcotics police units that served the dual purpose of combating narcotics and boosting state power for a nation experiencing internal insurgencies. Similarly, modernization theory played a foundational role in U.S. and United Nations crop-substitution projects in northern Thailand, where the Royal Thai Government (RTG), the United States, and the UN devised projects both to wean the indigenous Hmong from poppy farming in favor of exportable, licit, cash crops and to modernize the Hmong and other hill tribes. In Burma, the U.S. government supplied the military dictatorship in Rangoon with military hardware-airplanes and helicopters-to help put down ethnic insurgents garnering financial support from opium production. The United States chose this counterinsurgency approach over a deal with ethnic rebels to purchase Burma's annual opium harvest in exchange for development aid. In Mexico-the nation deemed of utmost importance for American drug control abroad-a technological approach to supply reduction took shape that promised to contain the nature from which illicit drugs sprang. South of the Rio Grande, where the First World gave way to the Third, U.S. and Mexican officials together engaged in the large-scale use of herbicides to destroy poppy and marijuana fields-fields that from Washington's and Mexico City's perspective funded antistate actors who threatened official authority.

In this sense, then, U.S. drug policy in Thailand, Burma, and Mexico intersected with issues of internal security. On the domestic front, away from the Third World sources of illicit narcotics, the Nixon and Ford administrations portrayed addiction as an antimodern, anti-American, foreign disease that necessitated destroying illegal drug production at its source. At the same time, the two Republi- 
can administrations created methadone maintenance and other demand reduction programs to reclaim domestic heroin addicts so they could function within a modern society. In all, examining counterinsurgency and modernization during the Nixon and Ford years illuminates not only the history of U.S. drug-control policy and the contours of U.S.-Third World relations but also the wider issue of culture as a crucial factor in American foreign relations. ${ }^{14}$ In order to study policy makers' cultural assumptions, an overview of how culture illuminates the history of American foreign relations and drug policy is required.

\section{American Foreign Relations as Cultural History and the History of Drug Control}

The application of the concept of culture-including literary theory, critical theory, gender theory, cultural anthropology, deconstruction, subaltern studies, and postcolonial studies - to the history of American foreign relations has received a great deal of attention, not only from diplomatic historians but also from those in the fields of American studies and literature. ${ }^{15}$ Scholars have looked at questions ranging from how gendered language and gender norms figured into foreign policy formation, ${ }^{16}$ to the way economic policy reproduced American cultural norms, ${ }^{17}$ to how racism and questions of the "other" influence and are reproduced through U.S. foreign policy. ${ }^{18}$ Finally and importantly, numerous studies analyze how scholars should best conceptualize interactions between cultures-through concepts such as "cultural imperialism" or "cultural transfer." ${ }^{19}$ Although many of these works employ the term culture ${ }^{20}$ as a category of analysis, the scholars doing so are not a homogenous group-their definitions of culture and the range of subjects studied vary considerably.

Given the multitude of ways that scholars have applied culture to their analyses, it is necessary to flesh out how to define the term and which methodologies and theories apply to an exploration of U.S. antinarcotics policy in Thailand, Burma, and Mexico. First, what is culture? Many historians have turned to the much-cited (and useful) definition of culture given by cultural anthropologist Clifford Geertz. For Geertz, culture is "an historically transmitted pattern of meanings embodied in symbols, a system of inherited conceptions expressed in symbolic forms by means of which men communicate, perpetuate, and develop their knowledge about and attitudes towards life." ${ }^{21}$ American foreign relations and drug policy historian William O. Walker III has fruitfully paraphrased Geertz's definition of culture as context, as "how people make sense of their environment and publicly order their behavior." 22

Using this broad definition Walker goes on to explain the numerous ways that culture aids in the study of foreign relations. Because of culture's "enduring nature," 
it allows scholars to recognize continuities of policy formation and implementation over time. For an examination of the drug war in Thailand, Burma, and Mexico from 1969 to 1976 , Walker's recommendations prove apt. Cultural continuity manifested itself in the persistent notion that domestic drug abuse originated from foreign producers and traffickers. ${ }^{23}$ The perception of drugs as a foreign scourge dated back to the origins of drug control in the United States at the turn of the twentieth century. Continuity of policy formulation and implementation is apparent in U.S. reliance on law enforcement, both domestically and abroad, as the primary means to allay drug abuse. Since drug abuse was born of a foreign source and legal measures were prescribed as the solution, American foreign drug policy has traditionally focused on source control. In other words, U.S. drug-control policy has sought to suppress the production of illegal drugs in other regions of the world and to interdict illicit drugs en route to U.S. markets. Also, culture aids in assessing an important aspect of foreign relations, the issue of how a policy affects its targets and how the targets negotiate, resist, and accept external policies designed to transform them. ${ }^{24}$

In the particular case of U.S. drug control in Thailand, Burma, and Mexico, a more specific explanation of how this broad view of culture is applicable and helps illuminate the contours of American foreign drug-control relations in the Third World is needed. Since this book explores the cultural and ideological underpinnings of U.S. narcotics control policy in three Third World states, it is useful to frame this exploration with the following question: How does one fight a war on drugs? From this question related queries emerge: To what historical and contemporary frames of reference did U.S. officials refer when trying to understand why opium was produced and trafficked in Thailand, Burma, and Mexico? How did American authorities come to understand the hill tribes in northern Thailand and northeast Burma, as well as the Mexican campesinos, who grew poppies? What exactly did illicit production threaten in the source countries and the United States, and did the governments of Thailand, Burma, and Mexico share Washington's perception of the threat? Conversely, how did the producers' and traffickers' perception of the drug trade correspond with American explanations for their production?

These questions explore the fact that opium growers, traffickers, the source countries' governments, and the U.S. government all endowed drug use, production, and trafficking with meaning. Drugs-in this case narcotics (opium and heroin)-were powerful symbols for each of these actors. What type of cultural logic lay behind the meanings ascribed to these symbols? Lastly, what is the connection between the cultural meanings the American, Thai, Burmese, and Mexican governments ascribed to drugs and their policies that sought to control drug production and trafficking? What was each government trying to achieve? And how did the targets of drug-control policy respond to these governments' efforts to implement source control? All of these questions directly relate to Walker's acute statement that "the study of drugs necessarily becomes a study of cultures 
in competition ... [ [and] the history of drugs, more than simply a study of drug control, is fundamentally a study of culture."25

If drugs are assigned cultural meaning by growers, traffickers, and the governments that try to eradicate them, culture is applicable to the study of drug control. Growers, for instance, often assign economic or ritual meaning to poppy farming, while government authorities assign very different meanings to poppies. Poppies are equated with addiction and the threat of societal decay rather than seen as a plant that supplies economic stability and/or ritual significance. Thus, growers, traffickers, and users constitute a drug culture while the governments and institutions charged with halting drug production and use constitute another culture, a culture of drug control. Even as we broadly define culture as how people understand the world around them and from this understanding order their "public behavior," as Walker has stated, we can analyze the specific meanings attached to drugs and how they function within either drug subcultures or cultures of drug control.

One useful way of delineating the cultural significance of drugs is by examining the discourses that actors use to endow drugs with meaning. Michel Foucault has argued that discourses are more than just the words used to discuss or describe a given subject, whether that subject is capitalism, baseball, or drug addiction. Discourse is not transparent language that merely reflects a separate, fixed, and transcendent "reality." Instead, as theorist Sarah Mills has pointed out, "discourse is something which produces something else (an utterance, a concept, an effect), rather than something which exists in and of itself and which can be analysed in isolation." ${ }^{26}$ Discourses are about the production of truth, and throughout the modern era societies have constructed discourses that assert and exert truth claims. Discourse production is the practice of actively choosing of what is included and excluded from what is regarded as true. In sum, discourses are active "practices that systematically form the objects of which they speak." 27 Thus, discourses do have very concrete consequences. Discourse is not just about signification and meaning production, but about the material effects of that truth production upon societies. $^{28}$

Given this conception of discourse, one can argue that from a discourse's truth production arises the power to enact that truth in society. Contrary to common perceptions of power as restrictive, a discourse's power is not only repressive but also constitutive - that is, discourses set up "power relations [that] produce forms of subjectivity and behavior rather than simply repressing them." ${ }^{29}$ For instance, drug policy derives power from addiction discourses characterizing addiction as a physical and social disease that destroys an individual's free will and produces social and economic harm. Drug policy is both prescriptive and proscriptive in that it not only represses behavior (for example, consuming heroin) but also produces and reinforces "normal" behavior (for example, self-discipline, sobriety, and socially productive work). The "truth" of addiction discourses is dispersed 
throughout society by the bureaucratic and institutional apparatuses of the state, which enforce drug laws, as well as by nonstate actors, such as schools, churches, and the medical community.

Employing discourse analysis in this way benefits the study of American foreign relations because policy makers draw upon discourses to make sense of their subjects. In studying the various facets of foreign relations, one can continually ask, How do policy makers construct their subjects? Scholars such as Emily S. Rosenberg, Nick Cullather, Andrew J. Rotter, and Mary A. Renda have successfully applied this question to analyses of U.S. dollar diplomacy, modernization theory, U.S.-Indian relations, and the American occupation of Haiti. Their works have demonstrated how the discourses of race, monetary exchange, gender, and paternalism, for example, have influenced and shaped U.S. foreign policy. ${ }^{30}$ This method of analysis puts these studies in line with the overall concerns of cultural history, which is, as Mark Poster explained, "the question of the construction of the subject." ${ }^{31}$

Similarly, because this study analyzes how U.S., UN, Thai, Burmese, and Mexican officials and drug cultures regarded modernization, counterinsurgency, and drugs, these topics are treated as transnational issues. That is, even though this study focuses on the ways in which U.S. drug policy was a product of American culture and history, it is important to realize the global context of "development," counterinsurgency, and drugs as transnational and dynamic phenomena that meant different things to different actors. In each nation, for example, they were connected to issues of national identity formation and fears over domestic security. This study also applies throughout Antonio Gramsci's theory of hegemony-the interplay of consent and coercion among elements of civil society and the state in establishing and maintaining official authority - to explain how the various actors in each culture contested the meaning and substance of modernization and drugs. U.S. drug policy intervened in the process of hegemony in Thailand, Burma, and Mexico on the side of official authority, which vied with subcultures - the hill tribes in Thailand, the Shans in Burma, the campesinos of Mexico, and the drug traffickers in all three nations-over who and what constitutes a legitimate nation.

Regarding the particulars of this study-U.S. antinarcotics policy in Thailand, Burma, and Mexico from 1969 through 1976-the discourses of modernization and counterinsurgency will be paramount. These discourses constituted distinct cultural constructions through which the U.S. authorities understood, defined, created, and implemented policies to halt poppy production and narcotics trafficking in all three nations. In essence, through these discourses American officials created their subjects. One may assert that these discourses do not fully explain U.S. drug policy in the three nations. This is true; modernization and counterinsurgency overlapped with other discourses-anti-Communism for one-while in each nation drug control was linked to the Cold War, links that will be explored. More importantly for our present theoretical discussion, modernization 
and counterinsurgency also intersected with older cultural forms, what Raymond Williams termed "residual" formations that still influence contemporary culture but are no longer dominant or authoritative in their explanations of reality. ${ }^{32} \mathrm{~A}$ relevant residual form that intersected and informed modernization and counterinsurgency and exerted cultural resonance was imperialism.

A particular feature of imperialism, as practiced in the nineteenth and early twentieth centuries, has resonance with U.S. drug control in Thailand, Burma, and Mexico: its "civilizing mission." The concept of American officials "tutoring" Third World governments and peoples on how to combat drug trafficking echoes the "civilizing mission" that motivated U.S. policies toward the Philippines and Native American reform movements and Western European imperialism in Asia and Africa. From the era of nineteenth-century Western imperialism up to and through the Cold War, the United States has tutored those its leaders considered underdeveloped (previously termed "uncivilized") in modern ways. As part of its anti-Communist mission during the Cold War, the United States tutored Third World nations through military assistance and development aid. American drug policy in Thailand, Burma, and Mexico continued the theme of Western tutoring of Third World peoples.

In exploring the effect that dominant discourses of modernization and counterinsurgency had on the formation of U.S. drug policy, as well as the ways in which residual forms informed narcotics control, it becomes clear that what developed in the 1970s was a new discourse of drug control-what Williams theorized was an emergent form. ${ }^{33}$ Between 1969 and 1976, the cultural foundations of what is presently termed the "drug war" were solidified. During those years, the direction of U.S. drug policy was in flux, and a number of new approaches-such as funding cropsubstitution programs among the hill tribes in Thailand-were taken. Some policies became permanent features of U.S. drug-control efforts, while others were rejected. Examining the discourses that conceptualized U.S. policy reveals why certain paths were chosen to the exclusion of others. In the end, these policy choices rested on discourses that proclaimed the reality of the drug trade and drug addiction.

This study will unfold chronologically, beginning in 1969 and concluding in 1976, with each chapter focusing on a specific relevant topic: the role of the disease metaphor, COIN, and modernization theory within American drug policy aimed at Thailand, Burma, and Mexico. The "drug war," as it is commonly conceived of today, began with the Nixon administration and evolved during the first half of the 1970s. The chronological approach is necessary because, after the declaration of a drug war, American antidrug policies at home and in Southeast Asia and Mexico were not fixed. The Nixon administration's antinarcotics policies did draw on prior drug policy, primarily its source-control focus and nativist thought. But drug control under Nixon also charted new waters, such as the increased training 
of antidrug forces abroad, support for crop-substitution programs and domestic methadone maintenance programs, and debate over a preemptive buy of illicit opium as an alternate form of source control.

Over the eight years covered in this study, many drug-control policies were implemented; they then either became permanent features of the American drug war or they were ended. For instance, the emphasis on source control persisted and was never seriously challenged, as was the notion that drugs were a debilitating foreign scourge. A relatively new aspect of drug control that emerged in the Nixon and Ford years was the mixing of COIN and modernization theory within American antidrug policy. The influence of COIN and modernization theory on American drug control abroad persisted through the rest of the twentieth century; Plan Colombia, for instance, was seemingly intended to aid the Colombian government in simultaneously defeating "narco-rebels" and stopping the production of illegal cocaine. ${ }^{34}$

Other tactics failed to become permanent features of the American drug war. These included preemptive purchases of illicit drug crops and substantive federal support for domestic methadone maintenance programs. The 1975 Shan proposal ${ }^{35}$ received important attention, but ultimately it was rejected as a form of source control; since then, preemption has not reemerged in serious drug policy debate with regard to Southeast Asia or any other part of the world. Nixon's experiment with federally funded methadone maintenance programs as a form of demand-side drug control initially received energetic federal attention, but that attention waned over the course of the 1970 for reasons to be discussed in later chapters.

Chapter 1 sketches the history of drug use in the United States and the development and implementation of drug-control policies domestically and abroad. From the time of the nation's founding through the mid-1970s (and beyond), drugs were an intertwined, yet often hidden, part of American history. Alcohol, cocaine, opium, morphine, and heroin followed similar historic arcs. Each drug, at one time or another, was legal and widely available. Then, following controversy and debate over its social, economic, and medical effects, it was made illegal. Only in the case of alcohol was prohibition repealed, while the substances we think of as "hard" drugs remained illegal for nonmedical use. Along with this proscription came the development of a system of laws and mores intended to punish addicts and those trafficking illegal drugs. Moreover, since opiate production originated outside American borders, U.S. attempts at drug control abroad concentrated on stopping illicit narcotics production overseas. The United States' supply-side approach to narcotics control was sometimes implemented unilaterally and sometimes multilaterally, such as in conjunction with the League of Nations or through the United Nations. A major aspect of U.S. supply reduction is the consistent belief that producer and transit nations must exert the political will necessary to enact source control within their national boundaries. In essence, the onus of source control lies with producer and transit nations, although the United States readily 
provides drug-control assistance. By the end of the 1960s, a global drug prohibition regime was firmly established among the world's leading nations and, at the same time, Southeast Asia and Mexico became the regions of importance for American antidrug efforts for reasons explored in subsequent chapters. Chapter 1 also historicizes addiction in U.S. history and illuminates how racial, gender, and class stereotypes were used to construct addicts as "others." Lastly, this chapter treats narcotics addiction as a problem and product of modernity. In other words, narcotics addiction emerged in the late nineteenth century as the United States transitioned into modernity and throughout the twentieth century addiction was viewed as antithetical to "modern" life.

One of the reasons Southeast Asia became a focus of American antidrug policies was the "heroin epidemic" among American servicemen in Vietnam that occurred between 1970 and 1972. Chapter 2 will focus on this heroin epidemic and then use that event as a way to examine the discourse of addiction and foreign drug policy, namely, the conception of drugs as disease. By fostering public fears that addicted returning soldiers would spread addiction throughout the country, thereby advancing addiction as a foreign-born contagion threatening the health of the United States, the Nixon administration maintained the long history of source control as the answer to addiction. This chapter consequently fully explores the drugs-as-disease metaphor and its effect on foreign policy and how drug policy is linked to national identity construction. As this chapter makes clear, official and public alarm allowed the Nixon administration to implement new antidrug legislation that greatly increased domestic and international narcotics law enforcement. Hence, the chapter provides an overview of the programs developed to stem abuse among soldiers in Vietnam and demonstrates how antidrug programs such as urinalysis became a means of making the subculture of heroin-using American servicemen "visible" to the U.S. government. Chapter 2 also addresses the significant social and cultural upheavals of the late 1960s and 1970s, placing the issue of drug control within the context of those upheavals, in which U.S. modernity and the Cold War consensus were in crisis, and exploring how the Nixon administration, with its "law and order" policies (including drug control), sought to contain domestic breakdown.

Finally, chapter 2 discusses U.S. drug control in Mexico in 1969 and 1970 as a way of framing and comparing later chapters' extended examinations of drug policy in Thailand, Burma, and Mexico. In the autumn of 1969, the Nixon administration initiated Operation Intercept-a supply reduction policy of strict searches of cross-border traffic that nearly closed the U.S.-Mexican border. Operation Intercept acted as a form of economic blackmail by the United States, which forced the Mexican government to undertake more vigorous and bilateral drug-control policies. Ultimately, Operation Intercept demonstrated two long-standing themes in U.S. drug policy-that producer and transit nations had to exert the political 
will to enact source control and that the U.S. sought to dominate drug-control relations with producer and transit nations (in this case, Mexico), coloring those relations with an air of paternalism. In Mexico, as well as in Thailand (and to a lesser extent in Burma), the U.S. government tutored its Third World partners in their source-control duties, and reward or punishment could follow.

Chapters 3 and 4 explore American anti-Communist and, chiefly, antinarcotics policies in Thailand. Just as the U.S. government sought to identify the drug subcultures among American soldiers, it did the same in Southeast Asia. Utilizing the cultural lenses of modernization theory and COIN, the United States cast its gaze on the Golden Triangle, the major opium-producing region of Southeast Asia, and, in accordance with modernization theory and COIN, it prescribed source-control policies. Following an overview of American application of COIN and development theory in Thailand, chapter 3 analyzes the U.S. drug war in that nation.

In Thailand, the United States employed development theory and COIN to create antinarcotics military and police units (covered in chapter 3 ) and to initiate, in conjunction with the United Nations, a crop-substitution program (the main focus of chapter 4 ). These efforts sought to increase state power and to integrate the opium-producing hill tribes, namely the Hmong, into the social, political, and economic mainstream of Thailand. In short, U.S. drug policies in Thailand endeavored to advance modernity and to make Thailand a modern state. To assess that goal, these chapters examine development and modernization from both U.S. and Thai perspectives and explore the history of imperialism, counterinsurgency, and modernization in Thai history. Throughout this examination, Orientalism emerges as a significant theme, playing a role in U.S. officials' perception of the Thais and in Washington's tutoring of the Thais in antinarcotics policies. Chapter 4 concludes with an appraisal of drug-control policy in Thailand.

Chapter 5 concentrates on Burma, considered by U.S. policy makers to be, along with Thailand and Mexico, a key country in the drug war. U.S. relations with Burma were not as friendly as those with Thailand or Mexico. Although the United States had little direct contact with Burma, which stridently asserted its neutrality, Burma was still part of the American drug war in Southeast Asia since it was the major producer of illicit opium. This chapter focuses on a unique event in the American drug war that involved Burma. In 1973, 1975, and 1977, ethnic rebels, the Shans, fighting for independence against the central Burmese government, offered to sell the annual harvest of illicit opium to either the U.S. government or an international agency. The 1973 preemptive buy proposal received little attention, but the 1975 and 1977 Shan proposals (particularly the 1975 offer) generated congressional attention that resulted in numerous hearings on the matter. Through an examination of the 1975 Shan proposal, this chapter explores how modernization became a common language between the Shans and the U.S. government and how the proposal illustrated an alternate direction that 
source control could have taken. In examining why the State Department and the DEA rejected the proposal, this chapter demonstrates U.S. officials' application of modernization and counterinsurgency theory to drug control in Burma.

Chapter 6 analyzes U.S.-Mexican drug policy in the Ford years-namely, the initiation of herbicide poppy eradication in Mexico. Links existed between U.S. drug control and Mexico's "dirty war" against political dissenters and insurgent groups. As in Burma, where counterinsurgency greatly influenced U.S. policy, Washington's drug-control policy toward Mexico was intended not only to stem the production and trafficking of narcotics but also to promote internal security within Mexico as its government faced rebel groups and economic instability. Likewise, as with the Burmese and Thais, U.S. authorities tutored the Mexicans in how and why to fight a drug war.

The conclusion reexamines the history covered in previous chapters and offers some observations about the role of counterinsurgency and modernization within U.S. drug policy in Southeast Asia and Mexico. This chapter also analyzes the longterm effects of American drug policy in Thailand, Burma, and Mexico and reframes U.S. source-control policy as a "faith" sustained by the discourses scrutinized in this study: drugs as disease, counterinsurgency, and modernization. 